HORTSCIENCE 26(7):921-923. 1991.

\title{
Growth and Composition of Passion Fruit (Passiflora edulis) and Maypop (P. incarnata)
}

Harvey E. Arjona, Frank B. Matta, and James O. Garner, Jr. Department of Horticulture, P.O. Drawer T, Mississippi State, MS 39762

Additional index words. postharvest, sugars, $\mathrm{pH}$, passion flower

Abstract. Fruit growth (diameter) of purple passion fruit (Passiflora edulis Sims.) and maypop ( $P$. incarnata $L$.) followed a sigmoidal growth curve. Passion fruit were larger than either greenhouse-grown or wild maypop fruit. Wild maypop produced larger fruit than greenhouse-grown maypop. Yellow passion fruit had the lowest percentage of pulp and the highest soluble solids concentration (SSC) and greenhouse-grown maypop had the lowest SSC among the four groups tested. Purple and yellow passion fruit had lower juice pH than maypop. Wild maypop fruit had the highest sucrose content and purple passion fruit had the lowest. Yellow and purple passion fruit juice had higher fructose and glucose contents than did maypop juice.

A wild type of passion fruit known as maypop grows in several southern states in the United States. This wild type has been reported to grow as far north as Pennsylvania (Bailey and Bailey, 1976). Very little is known about this plant, since it is viewed mainly as a non-noxious weed, but there are indications that the fruit is edible and that it

Received for publication 7 Sept. 1990. Mississippi Agricultural and Forestry Experiment Station $\mathrm{Ar}$ ticle no. J-7542. The cost of publishing this paper was defrayed in part by the payment of page charges. Under postal regulations, this paper therefore must be hereby marked advertisement solely to indicate this fact. contains at least four alkaloids that may have pharmaceutical application (Pruthi, 1963). In addition, maypop has a potential use as a rootstock for yellow and purple passion fruit types. The tissues forming the rind of purple passion fruit are composed of a thin layer of wax and five layers of schlerenchymatous tissue (Pruthi, 1963). Fruit of maypop have a much thinner and softer rind that easily collapses (Arjona, 1990). The objective of our study was to compare some physicochemical characteristics of maypop and the commercial passion fruit types.

Maypop and purple passion vines were grown in the greenhouse during Summer 1989. At anthesis, eight flowers of maypop 


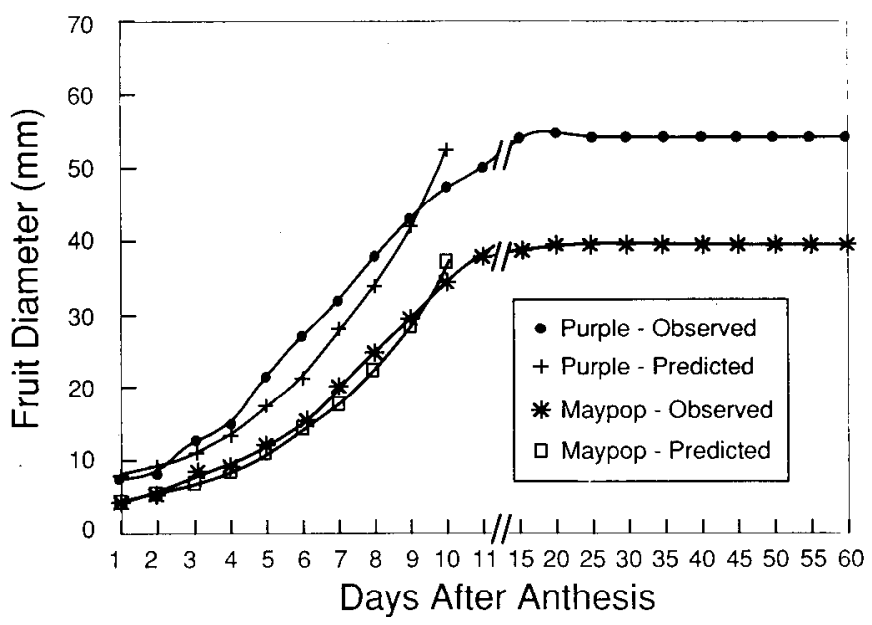

Fig. 1. Cumulative growth curves for purple passion fruit and maypop. Observed and predicted values are plotted for the exponential phase.

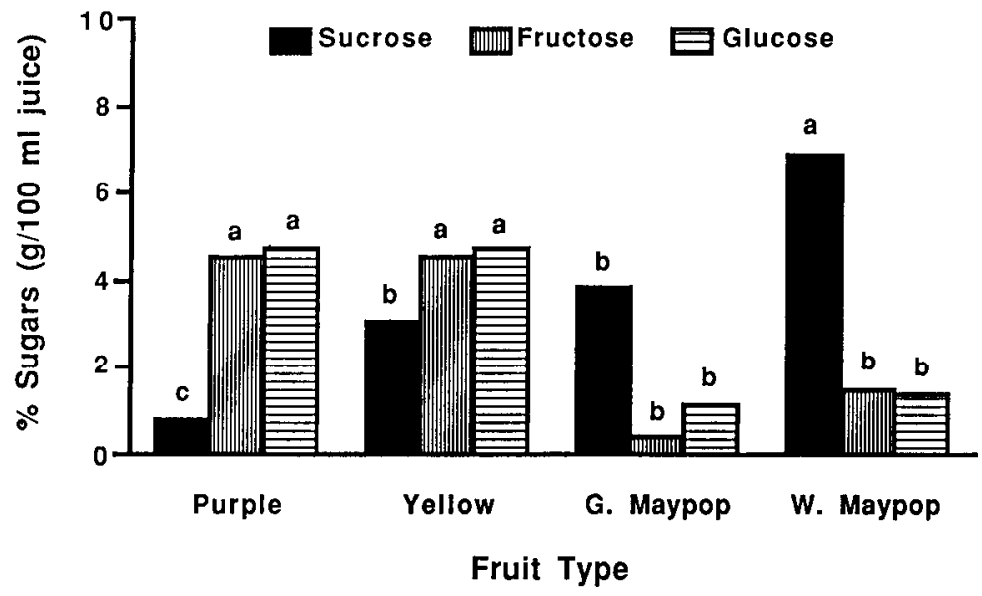

Fig. 2. Sugar content of purple and yellow passion fruit and greenhouse-grown maypop (G. maypop) and wild maypop (W. maypop). Mean separation by LSD (0.05) for each sugar.

Table 1. Some physical and compositional fruit characteristics of commercial passion fruit and maypop.

\begin{tabular}{lcrrrrrr}
\hline \hline & \multicolumn{3}{c}{ Wt (g) } & & \multicolumn{2}{c}{$\mathrm{SSC}^{\mathbf{z}}$} & \\
\cline { 2 - 5 } Plant type & Fruit & Rind & Pulp & Pulp (\%) & $(\%)$ & $\mathrm{pH}$ \\
\hline Passion fruit & & & & & & & \\
$\quad$ Purple & 59.6 & 27.6 & 30.0 & 53.6 & 12.9 & 3.1 \\
$\quad$ Yellow & 56.2 & 31.1 & 24.2 & 44.5 & 15.2 & 3.2 \\
Maypop & & & & & & \\
$\quad$ Greenhouse-grown & 15.1 & 5.7 & 9.4 & 58.1 & 9.1 & 3.5 \\
$\quad$ Wild & 38.5 & 13.0 & 25.1 & 66.3 & 9.5 & 3.6 \\
LSD (5\%) & 8.9 & 6.3 & 6.9 & 21.3 & 3.3 & 0.2 \\
\hline
\end{tabular}

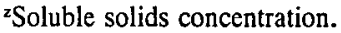

and eight of purple passion fruit on each of three plants were hand-pollinated with a small brush and tagged. The diameter of the ovary was measured with a Manostat caliper (Manostat, New York) at anthesis and between 1 and 10 days postanthesis (PA). Thereafter, diameter was measured at 5-day intervals until fruit had matured and were harvested (55 and 60 days PA for maypop and purple passion fruit, respectively). Fruit of maypop and of yellow and purple passion fruit were considered mature when the pericarp was soft to the touch for all three types and the fruit surface was $90 \%$ light green, purple, or yel- low, respectively. Data were analyzed by means of regression and the corresponding growth curves were plotted.

Flowers of wild maypop and commercially grown yellow passion fruit were tagged similarly as greenhouse-grown plants. Fruit from three plants (six per plant) were analyzed for external appearance, fruit weight, fruit rind weight, pulp weight, percentage of pulp, juice $\mathrm{pH}$, total soluble solids concentration (SSC), and for sucrose, fructose, and glucose contents of the juice. Sugars were quantified by means of high-performance liquid chromatography (HPLC). Fruit were cut in half, the pulp spooned out, and the juice and seeds separated by squeezing the pulp in two layers of cheesecloth. The juice was centrigued at $1500 \mathrm{x} g$ for $1 \mathrm{~h}$. The supernatant was collected and filtered through a Sep-Pack C-18 cartridge previously activated with $2 \mathrm{ml}$ of methanol and rinsed with $10 \mathrm{ml}$ of distilled water. The sample was filtered with a $0.45-\mu \mathrm{m}$ pore filter and injected into the HPLC system. Acetonitrile ( $80 \%$ in water) was used as solvent. A $10-$ $\mu \mathrm{l}$ sample was manually injected for every determination. The Waters Associates pump (Waters Assoc., Milford, Mass.) was set to deliver a flow rate of $2 \mathrm{ml} \cdot \mathrm{min}^{-1}$ at 10,550 $\mathrm{kPa}$. A carbohydrate analysis column in conjunction with a differential refractometer was used to quantify the sugars (both instruments, Waters Associates). Commercial samples of each sugar were used as standards. Sugar content in the fruit samples was calculated by means of regression. Juice $\mathrm{pH}$ was measured with an Accumet $\mathrm{pH}$ meter 925 (Fisher Scientific, Pittsburgh). Fruit rind and pulp weights were taken with a Mettler PE 160 electronic scale (Mettler, Highstown, N.J.). Pulp percentage was expressed as (pulp weight/total fruit weight) $\times 100$. SSC was determined with a 5.5 Bausch and Lomb (Rochester, N.Y.) optical refractometer. Analysis of variance, orthogonal contrasts, and LSD tests were performed to compare means between treatments (Peterson, 1985; Steel and Torrie, 1980).

Fruit growth (diameter) of both maypop and purple passion fruit followed typical sigmoidal kinetics (Fig. 1) (Wareing and Phillips, 1986). The Wilks' lambda test or test of parallel profiles (Hair et al., 1984) showed that there were no differences in growth rate between maypop and purple passion fruit during the exponential phase. The exponential phase of fruit growth in both species occurred between anthesis and $\approx 7$ days PA. The inflection point occurred between day 7 and day $8 \mathrm{PA}$, and the curve started leveling off 12 days PA (Fig. 1).

Fruit of purple and yellow passion fruit were heavier than those of greenhouse-grown or wild maypop fruit (Table 1). Fruit of wild maypop was significantly heavier than that of greenhouse-grown fruit (Table 1). Greenhouse-grown maypop fruit produced few seeds (between 15 and 20 per fruit) compared to wild maypop fruit ( $\approx 60$ or more per fruit). Pruthi (1963) reported a close positive correlation between the number of seeds and final fruit diameter. Wild passion flowers are cross-pollinated by insects, resulting in many seeds and larger fruits. The four fruit used in this experiment were grown in three environments. Commercial yellow passion fruit were grown in Homestead, Fla.; commercial purple passion fruit and maypop were grown under greenhouse conditions in Starkville, Miss. The wild-type maypop grew in Starkville. The yellow and the purple types had significantly heavier rinds than the maypops (Table 1). Rind weight for yellow and purple passion fruit was similar. Wild-growing maypop had a significantly higher rind weight than greenhouse-grown maypop (Table 1). 
Purple passion fruit had higher pulp weight than yellow passion fruit or the maypops. Greenhouse-grown maypop fruit had the lowest pulp weight of all fruit (Table 1). Passion fruit pulp is formed by the seeds and the aril that surrounds the seed and contains the juice. The purple passion fruit, which were grown in the greenhouse, were handpollinated. This procedure may explain why fruit in this treatment had a greater amount of pulp. Greenhouse-grown maypop fruit were not hand-pollinated. Differences in percentage of pulp were found only between yellow passion fruit and wild maypop fruits, the latter being $\approx 50 \%$ higher (Table 1 ).

The difference in SSC within fruit of the same species was not significant (Table 1). Pruthi (1963) reported minimum and maximum values of SSC between $14.4 \%$ and $21.9 \%$, with an average of $17.3 \%$, values that are higher than those we observed. SSC in purple passion fruit (12.9\%) was lower than the minimum value $(14.4 \%)$ reported by Pruthi and Lal (1959), but the SSC for yellow passion fruit was within the range reported by these authors.

Purple and yellow passion fruit had lower juice $\mathrm{pH}$ than the maypop fruits. The differ- ences in juice $\mathrm{pH}$ within species were not significant (Table 1). These results agree with those reported by Pruthi and Lal (1959), who found that purple passion fruit juice has a $\mathrm{pH}$ that varied between 2.6 and 3.2, with an average of 2.8 .

Wild maypop fruit had the highest sucrose content of all fruit types, and greenhousegrown purple passion fruit had the lowest. Yellow passion fruit contained more sucrose than did the purple type. (Fig. 2). The sucrose content of greenhouse-grown purple passion fruit $(0.83 \%)$ was considerably lower than the minimum value reported $(2.3 \%)$ by Pruthi and Lal (1959) for field-grown fruit, but the concentration $(3.1 \%)$ found in yellow passion fruit was within the range $(2.3 \%$ to $7.9 \%$ ) reported by them. Yellow and purple passion fruit contained more fructose than maypop. No differences in fructose were found within each species (Fig. 2). Glucose followed a trend identical to fructose. The values observed in this experiment for reducing sugars in commercial passion fruit agree with those reported by Pruthi and Lal (1959).

Work is needed to determine if the differences in composition between commercial passion fruit and maypop are related to consumer appeal.

\section{Literature Cited}

Arjona, H.E. 1990. Postharvest physiology studies of passion fruit (Passiflora edulis, Sims.). PhD Diss., Mississippi State Univ., Mississippi State:

Bailey, L.H. and E.Z. Bailey. 1976. A concise dictionary of plants cultivated in the United States and Canada. Macmillan, New York.

Hair, J.F., Jr., R.E. Anderson, R.L. Tatham, and B.J. Grablowsky. 1984. Multivarate data analysis. Macmillan, New York.

Peterson, R.G. 1985. Design and analysis of experiments. Marcel Dekker, New York.

Pruthi, J.S. 1963. Physiology, chemistry and technology of passion fruit. Food Res. 12:138142.

Pruthi, J.S. and G. Lal. 1959. Chemical composition of passion fruit (Passiflora edulis Sims). J. Sci. Food Agr. 10:188-192.

Steel, R.G.D. and J.H. Torrie. 1980. Principles and procedures of statistics. A biometrical approach. 2nd ed. McGraw-Hill, New York.

Wareing, P.F. and I.D.J. Phillips. 1986. Growth and differentiation in plants. 3rd ed. Pergamon Press, New York. 